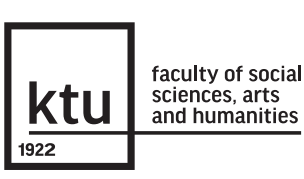

SAL 38/2021

Research Journal Studies about Languages pp. 17-28

ISSN 1648-2824 (print) ISSN 2029-7203 (online) DOI 10.5755/j01.sal.1.38.27396
TRANSLATION / VERTIMAS

Culture-Specific Information Encoded in Lacunae: The Author's and Translators' Strategies of Representation
Accepted 04/2021
Received 07/2020 rrossef http://dx.doi.org/10.5755/j01.sal.1.38.27396
HOW TO CITE: Slavova, L., \& Borysenko, N. (2021). Culture-specific information encoded in lacunae: The author's and translators' strategies of representation. Studies about Languages / Kalbų studijos, 38, 17-28. http://doi.org/10.5755/j01.sal.1.38.27396

\title{
Culture-Specific Information Encoded in Lacunae: The Author's and Translators' Strategies of Representation
}

\author{
Specifinès leksinių atitikmenų neturinčios kultūrinès \\ informacijos perteikimo strategijos
}

\author{
LIUDMYLA SLAVOVA, Taras Shevchenko National University of Kyiv, Ukraine \\ NATALIA BORYSENKO, Zhytomyr Ivan Franko State University, Ukraine
}

\begin{abstract} rina Lewycka's novel A Short History of Tractors in Ukrainian. Such information is encoded in lacunae and the author's or translator's task is to decode it using relevant translation strategies. The latter ones have been identified: 1) the strategy of domestication (equivalent or near equivalent translation); 2) the combination of domestication and foreignization (transliteration together with a near equivalent and descriptive translation, calque translation accompanied by descriptive translation); and 3) the strategy of foreignization (borrowing, transliteration alone or combined with calque translation). Graphic means such as inverted commas and italics are used to mark information as culture-specific for the reader. Ukrainian and Russian translations of the novel demonstrate that lacunae are rendered mostly with the help of the corresponding Ukrainian and Russian lexemes. It has been revealed that archaic forms can be substituted by modern ones, and both native and borrowed elements are employed. This paper also demonstrates that the procedures and means used in rendering Ukrainian culture-specific information in the source English and target Ukrainian and Russian texts aim at finding balance between the strategies of domestication and foreignization used in the presentation of culture-specific information.
\end{abstract}

The present study examines the representation of Ukrainian culture-specific information in Ma-

KEYWORDS: culture-specific information, lacuna, translation, domestication, foreignization.

\section{Introduction}

It has been assumed that the unique character of a certain culture is revealed in culture-specific information, i.e., the one which is not found outside the community. The present study deals with the presentation of this information in Marina Lewycka's first novel $A$ Short History of Tractors in Ukrainian (first published in 2005) written in English and its translations into Ukrainian by Oleksa Negrebetskyi (2013), a prominent Ukrainian translator from English, and into Russian by Valeriy 
Nugatov (2006), a Russian-Ukrainian poet, prose writer and translator, who has a good command of Ukrainian, which reasonably excludes any misunderstanding of Ukrainian culture-specific information. It should be noted that Lewycka is an ethnic Ukrainian, born in a Ukrainian family and brought up in England. The novel is an autobiographical story of a family that lived in Ukraine before the Second World War (WWII), survived the war and emigrated to Great Britain. The scene is laid in the 1990s, when the mother dies and the elderly father decides to marry a young divorcee from Ukraine. The novel describes how the middle-aged daughters try to prevent their father from marrying someone whom they consider to be an adventuress and how the memories of the past influence their life. The author introduces her family history starting with the beginning of the $20^{\text {th }}$ century and describes the events (WWI, the revolution of 1917, and the Civil War), which took place on the territory of Ukraine. To reflect the life of people in Ukraine in the novel targeted for the English reader is, to some extent, a challenge for the writer. Ukrainian culture-specific information is to be presented in a clear and unambiguous way and to be adequately perceived by the intended audience. This situation is treated in our research as a case of intercultural communication, which, on a broad scale, is viewed as a contact of people from different cultural and linguistic backgrounds (Piller, 2007) or communication activities involving parties of different cultural backgrounds (Chen, 2017). Thus, the author of the novel acts as an intercultural mediator who solves the problems of interaction, which arise due to cultural discrepancies (Akbari \& Darani, 2017, p. 60). Such problems are similar to those which occur in the process of translation. Moreover, when the novel is translated into Ukrainian and Russian, further transformations in the presentation of Ukrainian culture-specific information occur, as the majority of the phenomena described are historical ones and are connected with the previous epoch.

The purpose of this research is to identify and describe techniques within the strategies of domestication, foreignization and their combination used for rendering Ukrainian culture-specific information in Lewycka's novel A Short History of Tractors in Ukrainian and in its target Ukrainian and Russian texts.

Theoretical Background
Culture-specific lexical units have been the object of investigation in cultural linguistics, country study (Vlakhov \& Florin, 1980), psycholinguistics (Lyubymova et al., 2018), ethnolinguistics (Markovina, 2004), and translation studies (Newmark, 1988; Nida, 2003). It is argued that the term lacuna is employed by the majority of scholars, when it comes to differences in languages and cultures (Dun, 2007). Lacunae, culture gaps, i.e., items of language, text or culture, are partially or completely unintelligible in another culture (Lyubymova et al., 2018). They are subdivided into lexical, grammatical, functional, relative or absolute, and do not have equivalents in other languages or cultures (Markovina, 2004; Kazazi 2014). Cultural lacunae, in their turn, are viewed as extralingual problems of intercultural communication (Markovina, 2004). These are words and word combinations, which reflect names of objects, notions, phenomena, everyday objects, characteristic features of geographical position, culture, social and historical features of the ethnic or cultural community. They encode an important part of information about the community naming historical events, objects of material culture, institutions, or prominent people absent in other societies (Slavova \& Borysenko, 2018). In translation studies, lacunae are defined as cultural words, i.e., lexemes that are associated with a definite language and present difficulty in translation. They are subdivided into categories reflecting such spheres of life as ecology, material and social culture, organizations, traditions, customs, activities, procedures, concepts, habits and gestures (Newmark, 1988). In Soviet and post-Soviet tradition, lacunae are believed to have a cultural component which unites a complex of associations arising in the consciousness of the native speaker due to the image of the word. Such lexical items name objects and phenomena, characteristic of one culture and absent from the rest (Yemelyanova, 2010). Consequently, words with cultural components reflect the unique character of a certain culture.

Another name for lacunae is реалія/реалия/realia [Eng. culture-specific item], which is quite popular in Eastern Europe, including Ukraine, and signifies both unique phenomena that are present in the life of just one community (Vlakhov \& Florin, 1980) and the words which name such phenomena. In contemporary Ukrainian translation studies, peaліï [Eng. culture-specific items] are defined as mono or poly lexemes which contain in their meaning a complex of ethnic and cultural information alien to other languages and cultures (Zorivchak, 1989). These are lexemes without complete or partial equivalents in other languages (Shveytser, 1988) that are rendered in the target language with the help of special means (Zorivchak, 1989). 
This, in its turn, makes the process of understanding lacunae outside a definite community problematic, and leads to various kinds of distortions, when they are rendered in translation. Translating them consists of reproducing the most suitable natural equivalent of the source language message, both in terms of meaning and in terms of style (Nida, 1964; Nida \& Taber, 1969). The task of the translator or the author writing for a foreign community is to define and interpret culture-specific information from the standpoint of the target culture and act as an intercultural mediator (Akbari \& Darani, 2017).

Predominantly, two basic strategies, domestication, which takes into account the needs of the target audience, and foreignization, which preserves the foreign character of the culture-specific information (Eco, 2001), determine the way of rendering a given culture-specific element. Moreover, it is the context that influences the choice of this or that technique and lexical means in rendering lacunae (Ramiere, 2006). The techniques employed by the writer dealing with the representation of foreign culture-specific things, events, phenomena in the source text and by the translator, while rendering those lacunae in the target texts, are determined by the necessity to introduce the unique nature of Ukrainian culture to the readers of the source and target texts.

Methodology of one culture to the readers of another culture, the writer uses the same techniques in rendering cultural lacunae as translators do. The same can be said about the ways of introducing historical phenomena, which are of no relevance at present.

The text of the novel A Short History of Tractors in Ukrainian by Lewycka and its translations into Ukrainian and Russian serve as material of our research. There are several reasons for choosing this novel for the analysis:

1 the British writer is of Ukrainian origin, which allows depicting Ukrainian life viewed from the perspective of life in Great Britain;

2 the historical period depicted in the novel forces the writer to think of the ways of presenting certain events going back to different times;

3 the author has to choose linguistic means for both designating anthroponyms, political notions, historical events and objects of everyday life.

The above mentioned research principles determine the methods applied in the study for the analysis of the lacunae. During the first stage, sampling was made up based on the English text of the novel. Then we applied a knowledge-based approach, meaning that each culture-specific item was interpreted on the basis of relevant English and Ukrainian dictionaries. At this stage, we clarified the meaning of the lexemes under study, and stated whether there were any equivalents in the English language to the notions designated by a certain lacuna. English dictionaries were employed to study the lexicographic description of the words Lewycka uses in order to clarify Ukrainian culture-specific information. At this stage, componential analysis was applied to the material as it was helpful to study lacunae "first in context, then in isolation, as though it were a dictionary or an encyclopedia entry only and finally in context again" (Newmark, 1988, p. 17).

Further research involved the use of textual and contextual analyses. The former allowed us to focus on the structure of the fragments in which the lacunae were found in the source text and in the target texts. The latter was used in order to characterise the lacunae in their historical, cultural and social contexts. Translational analysis was used while working on Ukrainian and Russian translations. It enabled us to specify the differences in the presentation of Ukrainian stereotypes in the source text and in the target texts. It also allowed us to single out techniques employed by the author and by the translators in order to make the lacuna understandable for a target reader, and specify transformations used in the translations of the novel in question.

Results and Discussion
On the basis of the results obtained, it can be concluded that, while introducing lacunae, Lewycka resorts to the strategies of domestication and foreignization, involving a number of techniques:

Domestication:

1.1 Equivalent translations; 
1.2 Near equivalent translations;

2 A combination of domestication and foreignization:

2.1 Transliterations (foreignization) accompanied by near equivalents, and descriptive translations (domestication);

2.2 Calque translations (foreignization) together with descriptive translations (domestication);

3 Foreignization:

3.1 Borrowings;

3.2 Transliterations;

3.3 A combination of transliterations and calque translations.

The first group of techniques presents equivalent or near equivalent translations within the framework of the strategy of domestication. The first subtechnique introduces equivalent translation used to name a phenomenon which played a very important role in the political history of Soviet Ukraine before WWII:

The girl, Ludmilla, was pretty enough, said Baba Nadia, but rather wild; and it was unfortunate, to say the least, that her father was an 'enemy of the people' (Lewycka, 2017, p. 68).

In the above example, the author uses a specific phrase enemy of the people. Although it originated as a term of Roman law in Ancient Rome in the form of hostis publicus (public enemy), it became popular after the October revolution of 1917 in Soviet Russia among the leaders of the revolution, who used the notion to designate their political opponents. Later, in the years of Stalin's terror, it labelled those who were not loyal to the Soviet power (Chernyavskaya et al., 2007). Of late, the term has been associated with President Trump's accusation of the press for making fake news (Kalb, 2018).

The Ukrainian translation reproduces the term in the form used in Ukraine in the 1930s (ворог народу):

Дівка, Людмила, сказала баба Надя, наче й гарна, тільки якась дика; та й батько в неӥ, м'яко кажучи, ворог народу [The girl, Liudmyla, baba Nadia said, is sort of pretty, but rather wild; and her father is, to put it mildly, an enemy of the people] (Lewycka, 2013, p. 61).

The Russian variant presents the phrase in inverted commas, imitating the English original text, which is quite unusual for the term that was in use in that historical epoch in Soviet Russia:

Людмила - красивая девушка, говаривала баба Надя, но с нею нет сладу; и, к превеликому сожалению, ее отеи, оказался "врагом народа» [Lyudmila is a pretty girl, baba Nadya used to say, but she is difficult to deal with; and, unfortunately, her father has turned out to be 'an enemy of the people'] (Lewycka, 2006, p. 81).

The use of the English equivalent for the term helps the author to preserve the atmosphere of that historical epoch. The translations also preserve the term, yet, somehow, the Russian variant introduces inverted commas, which are usually used to mark the presence of an alien notion in the text. This, in its turn, may be misleading for the target reader, who might misinterpret the meaning of the phrase.

The second subtechnique is also based on the equivalent translation and the substitution of a historical Ukrainian lexeme by a historical British one, which is better known in Great Britain and is easier to be decoded by the target reader:

The Ocheretkos were not gentry but wealthy peasants from the Poltava region of Ukraine...

(Lewycka, 2017, p. 50).

When the social status of the narrator's family is described, it is specified that they did not belong to the gentry. The dictionary articles give three groups of definitions of the lexeme gentry:

- Representatives of the aristocracy: aristocracy (Collins Free Online Dictionary).

- Those who belong to a high social class without naming its precise layer: persons of high birth or social standing (Collins Free Online Dictionary), people who belong to a high social class (Longman Dictionary of Contemporary English); 
- Those who are inferior to aristocracy: Br. persons just below the nobility in social rank (Collins Free Online Dictionary).

As the lexeme gentry is also used to describe those of a privileged position, who, nevertheless, do not belong to the nobility, there arises the question of its proper interpretation in the translations. When it comes to Ukraine, before the October revolution of 1917, the lexemes naming those who belonged to the privileged class of landowners are:

дворянство - панівний привілейований стан феодального (пізніше - i капіталістичного) суспільства, що складався з поміщиків і чиновників і мав основним джерелом доходу земельну власність [the ruling privileged class of feudal (later of capitalist) society, which consisted of landlords, and officials and had land ownership as the main source of income] (Bilodid, 1971, p. 225);

шляхта - дрібне дворянство колишньої феодальної Польщі, польське дворянство взагалі. Дворянство дореволюиійної України, Білорусії, Литви [szlachta (Polish) - petty nobility of the former feudal Poland, the Polish nobility in general. Nobility of pre-revolutionary Ukraine, Belarus, Lithuania] (Bilodid, 1980, p. 496).

The dictionary definitions show that the lexeme дворянство [nobility] and its variant дворяни [nobles] serve as hypernyms for the word шляхта [szlachta].

Both the Ukrainian and Russian translations comply with the strategy of domestication and the use of etymological equivalents: Ukrainian дворяни [nobles] and Russian дворяне [nobles]:

Очеретьки були не дворянами, а багатими селянами з Полтавської губернії в Україні... [The Ocheretkos were not gentry, but wealthy peasants from the Poltava region of Ukraine...] (Lewycka, 2013, p. 45).

Очеретки были не мелкопоместными дворянами, а зажиточными крестьянами из Полтавской губернии в Украине [The Ocheretkos were not petty nobility, but wealthy peasants from the Poltava region of Ukraine...] (Lewycka, 2006, p. 62).

At the same time, in the Russian translation the adjective мелкопоместный (владеющий небольшим поместьем [about nobility: owning a small estate] (Ozhegov \& Shvedova, 1995, p. 341) is used to specify the lexете дворяне. It must be noted that the English gentry is nearer to the Ukrainian шляхта in the meanings дрібне дворянство колишньої феодальної Польщі [petty nobility of the former feudal Poland] or дворянство дореволюційноі України, Білорусії, Литви [nobility of pre-revolutionary Ukraine, Belarus, Lithuania] (Bilodid, 1980, p. 496), and to the Russian шляхта - мелкопоместное дворянство (в Польше, Литве и ряде стран Центральной Европы) [landed gentry (in Poland, Lithuania and a number of countries of Central Europe)] (Yefremova, 2000). However, since the word gentry is polysemantic, it is not clear which meaning should be given priority in translation.

The third subtechnique presents the use of a near equivalent within the sentence analysed above in the phrase the Poltava region. The lexeme region is defined in the dictionary as an administrative area, division, or district (Dictionary by Merriam Webster) and is rendered in the translations with the help of Ukrainian and Russian correspondences.

Ukrainian губернія has the following meanings:

У Росії з початку XVIII cm. і в СРCP до районування 1929 р. - основна адміністративнотериторіальна одиниия [in Russia from the beginning of the $18^{\text {th }}$ century and in the USSR before the 1929 zoning the main administrative and territorial units] (Bilodid, 1971, p. 186); адміністративно-територіальна одиниця [administrative and territorial unit] (Busel, 2005, p. 265).

Russian губерния is defined in the dictionary in the following way:

Основная административно-территориальная единица в Российском государстве с начала XVIII в. и в СССР (до районирования в 1923-1929 г2.) [the main administrative and territorial unit in the Russian state from the beginning of the $18^{\text {th }}$ century and in the USSR (before the 1923-1929 zoning] (Yefremova, 2000). 
The translators' choices are therefore justified by the historical character of the lexical units губернія and губерния and by the time setting of the novel.

On the basis of a semantic analysis of the lexemes that represent similar phenomena in English and Ukrainian, the author and the translators take into account the historical and social context, thus applying the strategy of domestication, while introducing the lacunae.

Table 1 Representation of lacunae within the strategy of domestication in the target texts

\begin{tabular}{|c|c|c|c|c|c|}
\hline \multicolumn{2}{|c|}{ English source text } & \multicolumn{2}{|c|}{ Ukrainian translation } & \multicolumn{2}{|c|}{ Russian translation } \\
\hline lacuna & technique & lacuna & technique & lacuna & technique \\
\hline $\begin{array}{l}\text { 'enemy of } \\
\text { people' }\end{array}$ & $\begin{array}{c}\text { equivalent, } \\
\text { inverted commas }\end{array}$ & $\begin{array}{l}\text { ворог } \\
\text { народу }\end{array}$ & equivalent & «враг народа» & $\begin{array}{c}\text { equivalent, inverted } \\
\text { commas }\end{array}$ \\
\hline gentry & equivalent & дворяни & hypernym & $\begin{array}{c}\text { мелкопоместные } \\
\text { дворяне }\end{array}$ & equivalent \\
\hline region & near equivalent & губернія & historical equivalent & губерния & equivalent \\
\hline
\end{tabular}

The second group of techniques makes it possible to implement the combination of the strategies of domestication and foreignization, which aims at finding a balance between the process of preserving the foreign character of the described phenomena and making them clear to the reader.

The first subtechnique comprises a combination of transliteration with a near equivalent which is given in brackets, e.g., khutor (settlement):

... who lived on the edge of a khutor (settlement) and farmed some thirty hectares on the eastern bank of the Sula River (Lewycka, 2017, p. 50).

The author uses the graphic means of italics to introduce the transliterated word khutor, adds the lexeme settlement, which serves as an approximate English equivalent, although it does not fully correspond to the very specific notion of khutor.

In Ukrainian, хутір is defined as відокремлене селянське господарство разом з садибою власника [a detached peasant farm together with the owner's estate] or невелике селище, яке виникло внаслідок переселення людей з сіл, козачих станиць тощо; виселок [a small settlement that arose as a result of the relocation of the inhabitants from villages, cossack villages, etc, a new hamlet] (Bilodid, 1980, p. 176).

The Ukrainian translation does not give any explanation of the phenomenon хутір:

...вони жили на хуторі, обробляли тридиять гектарів землі на східному березі Сули [... they lived on the khutir, and farmed thirty hectares of land on the eastern bank of the Sula River] (Lewycka, 2013, p. 45).

The word хутор, however, is given in italics in the Russian variant:

Они жили на краю хутора и обрабатывали около тридиати гектаров земли на восточном берегу речки Сула [They lived on the edge of the khutor, and farmed about thirty hectares of land on the eastern bank of the Sula River] (Lewycka, 2006, p. 62).

Somehow, the technique used in the Russian translation seems excessive, as the word is present in the dictionaries of the Russian language: хутор - обособленный земельный участок с усадьбой владельца [а detached piece of land of the owner's estate] (Ozhegov \& Shvedova, 1995, p. 859). Besides, хутор is a typical Ukrainian settlement which can also be found in the South of Russia: небольшое селение на Украине, на юге России [a small hamlet in Ukraine or in the south of Russia] (Yevgenyev, 1999).

The second subtechnique lies in using calque translations together with the descriptive translation that makes it easier for the target reader to perceive the meaning of the phenomenon: 
After the revolution of 1917, Ocheretko joined neither the Russian White Army nor the Soviet Red Army (Lewycka, 2017, p. 51).

To make a lacuna clearer to the target audience, the author adds the specifying word, which allows for an appropriate interpretation and decodification of the phenomenon. In this case, the author explains the White Army and the Red Army by adding the adjectives Russian (which is understood as anti-Soviet) and Soviet which should clarify the ideological position of the armies during the Russian Civil War of 1917-1922.

Somehow, it is not clear whether the reader can easily understand the notions. It should be noted that Encyclopaedia Britannica has an article devoted to the Red Army, whereas the White Army is just mentioned in several articles (Encyclopaedia Britannica). The latter term is unlikely to be well-known in the English-speaking countries, in particular in Britain.

Both the Ukrainian and Russian translations do not need to explain the phenomena because they are wellknown in their respective countries. Thus, the adjectives Russian and Soviet are not added to the translations:

Після революції 1917 року Очеретько не пішов ні в Білу, ні в Червону армію [After the revolution of 1917, Ocheretko joined neither the White Army nor the Red Army] (Lewycka, 2013, p. 46).

После революции 1917 года Очеретко не пошел ни в Белую, ни в Красную армию [After the revolution of 1917, Ocheretko joined neither the White Army nor the Red Army] (Lewycka, 2006, p. 63).

The third subtechnique is based on transliteration accompanied by descriptive translation and a near equivalent:

Into the soup, when it was simmering, she dolloped teaspoons of 'halushki' - a paste of raw egg and semolina, beaten together with salt and herbs - which fluffed up into dumplings that crumbled on your tongue (Lewycka, 2017, p. 53).

The word галушки names a traditional Ukrainian food which can be either eaten as a separate dish or added to soup while it is cooked. In the source text, the transliterated lacuna 'halushki' is given in italics and inverted commas, accompanied by the explanation of what (a paste of raw egg and semolina) and how (beaten together with salt and herbs) the dish is cooked, and a near English equivalent dumplings, in order to make it clear for the target reader. The dumplings are traditional British and Irish dishes.

In the Ukrainian translation, there is no necessity to compare the traditional Ukrainian dish галушки to any other foodstuffs, thus, the information about dumplings is omitted:

У суп, поки він кипів на повільному вогні, мати досипала галушки - як чайна ложечка завбільшки шматочки тіста з манки, перемішаної з сирими яйцями, сіллю та травами. Зварившись, вони ставали пухкі й танули на язиці [Into the soup, while it was simmering, Mother dolloped halushki which were the teaspoon size pieces of dough from semolina mixed with raw eggs, salt and herbs. When cooked, they fluffed up and crumbled on your tongue] (Lewycka, 2013, p. 48).

At the same time, the Russian translation imitates the technique of the source text, preserving the Ukrainian lacuna галушки and comparing the Ukrainian dish to a Russian one: which is better known to the Russian reader:

Пока варился борщ, мама готовила тесто из сырого яйца и манной крупы, взбитое вместе с солью и травами, и с помощью чайной ложки лепила из него галушки украинские клецки, которые, разбухая в воде, так и таяли во рту [While the borsch was cooked, Mum prepared dough from a raw egg and semolina, beaten together with salt and herbs, and with the tea spoon formed galushki - Ukrainian Knödel which fluffed up in the water and crumbled on your tongue] (Lewycka, 2006, p. 66).

The word галушки is found in several dictionaries of the Russian language that provide an explanation of how to cook the dish. For example, it is defined as украинское кушанье - кусочки сваренного теста [Ukrainian dish: pieces of boiled dough] (Ozhegov \& Shvedova, 1995, p. 122); украинское кушанье: кусочки теста, сваренные в супе или молоке [Ukrainian dish: pieces of dough cooked in soup or milk] (Ushakov, 1935); украинское кушанье 
в виде кусочков сваренного теста [Ukrainian dish in the form of pieces of boiled dough] (Yefremova, 2000). Clearly, these definitions emphasise the ethnic character of the dish. Nevertheless, in the Russian translation, the dish галушки is associated with the European dish клецки (from German Knödel). The word клецки is borrowed from German and is defined in the dictionary as кусочки теста (из манной крупы, пшеничной муки), сваренные в бульоне, молоке [pieces of dough (from semolina, wheat flour) cooked in broth, milk] (Ozhegov \& Shvedova, 1995, p. 271). Thus, the translator uses two borrowed words, one Ukrainian and the other German, in order to help the target reader understand the lacuna better. In other words, the Ukrainian word галушки needs explanation in English and in the Russian target text, whereas it is clear to the Ukrainian reader without additional information.

Table 2 Representation of lacunae within the strategy of domestication combined with the strategy of foreignization

\begin{tabular}{|c|c|c|c|c|c|}
\hline \multicolumn{2}{|c|}{ English source text } & \multicolumn{2}{|c|}{ Ukrainian translation } & \multicolumn{2}{|c|}{ Russian translation } \\
\hline lacuna & technique & lacuna & technique & lacuna & technique \\
\hline $\begin{array}{c}\text { khutor } \\
\text { (settlement) }\end{array}$ & $\begin{array}{l}\text { transliteration, near } \\
\text { equivalent, italics }\end{array}$ & хутір & equivalent & хутор & $\begin{array}{l}\text { equivalent, } \\
\text { italics }\end{array}$ \\
\hline $\begin{array}{l}\text { Russian White } \\
\text { Army }\end{array}$ & equivalent & дворяни & hypernym & $\begin{array}{c}\text { мелкопоместные } \\
\text { дворяне }\end{array}$ & equivalent \\
\hline $\begin{array}{l}\text { Soviet Red } \\
\text { Army }\end{array}$ & $\begin{array}{l}\text { calque translation, de- } \\
\text { scriptive translation }\end{array}$ & $\begin{array}{l}\text { Біла, Червона } \\
\text { армія }\end{array}$ & equivalent & $\begin{array}{c}\text { Белая, Красная } \\
\text { армия }\end{array}$ & equivalent \\
\hline $\begin{array}{l}\text { 'halushki' } \\
\text { dumplings }\end{array}$ & $\begin{array}{l}\text { transliteration, near } \\
\text { equivalent, descriptive } \\
\text { translation, inverted } \\
\text { commas, italics }\end{array}$ & галушки & equivalent & $\begin{array}{c}\text { галушки } \\
\text { Украинские } \\
\text { клецки }\end{array}$ & $\begin{array}{c}\text { borrowing, } \\
\text { descriptive } \\
\text { translation, near } \\
\text { equivalent }\end{array}$ \\
\hline
\end{tabular}

The third group of techniques allows implementing the strategy of foreignization, which aims at preserving the atmosphere of a foreign culture unknown to the target reader.

The first subtechnique is based on the usage of the word which was borrowed into English from Russian, and defines a typically Eastern Slavic phenomenon:

The Mayevskyjs were part of the small Ukrainian intelligentsia (Lewycka, 2017, p. 68).

The English lexeme intelligentsia is an early 20th century Russian borrowing, referring to intellectuals who form an artistic, social, or political vanguard or elite, which has been known since 1905 (Dictionary by Merriam-Webster). In the Ukrainian and Russian translations, the etymological correspondences інтелігенція / интеллигенция [intelligentsia] are used, which is explained by the popularity of the word intelligentsia in the former USSR, when it comes to the people involved in intellectual labour:

Маєвські належали до нечисленної української інтелігенції (Lewycka, 2013, p. 61).

Маевские принадлежали к немногочисленной украинской интеллигенции (Lewycka, 2006, p. 81-82).

The dictionary of Modern Ukrainian defines інтелігенція аs люди розумової праці, що мають спеціальні знання з різних галузей науки, техніки й культури [people of mental labour who have special knowledge in various fields of science, technology, and culture] (Bilodid, 1973, p. 360). The lexeme is borrowed via Russian and Polish from Latin intellegentia meaning 'understanding, an ability to perceive knowledge' (Melnychuk et al., 1985, p. 309-310).

The Dictionary of the Russian language defines интеллигенция as люди умственного труда, обладающие образованием и специальными знаниями в различныхобластяхнауки, техникии культуры; общественный слой людей, занимающихся таким трудом [реople of mental labor with education and special knowledge in various fields of science, technology and culture; the social stratum of people engaged in such work] (Ozhegov \& Shvedova, 1995, p. 244). The concept was introduced into the academic world in the 1860s, yet somehow it did not enjoy popularity outside the Russian empire and the USSR (Shynkaruk et al., 2002). 
The second subtechnique is based on transliteration alone, and provides no explanation of the lacuna which may cause difficulty in the perception of, for instance, an outdated form of patronymic. In the source text, we come across the version which was used before 1917 and is no longer in use now. This is explained by the fact that the narrator's mother was born before 1917:

Ludmilla (Milla, Millochka) Mitrofanova was born in 1912 in Novaya Aleksandria, a small garrison town in what is now Poland, but was then on the western flank of the Russian Empire. Her father, Mitrofan Ocheretko, was a cavalry officer, a war hero, and an outlaw (Lewycka, 2017, p. 50).

The problem is that this kind of patronymic (Mitrofanova) coincides with a feminine form of the Russian surnames and might mislead the reader who knows little about the Ukrainian culture before 1917, although the second sentence, where the father's name is given (Mitrofan Ocheretko), can be looked upon as a clue.

Both the Ukrainian and Russian translations ignore the old form of the patronymic and use a contemporary version instead (Митрофанівна / Митрофановна). This can be explained because this historical form Митрофанова might be misleading for the contemporary reader:

Людмила (Міла, Мілочка) Митрофанівна народилася 1912 року в Новій Олександрії гарнізонному містечку, яке тепер належить Польщі, а тоді це був західний край Pосійської імперії [Liudmyla (Mila, Milochka) Mitrofanivna was born in 1912 in Nova Oleksandria, a small garrison town, which belongs to Poland now and which was the western outskirts of the Russian Empire then] (Lewycka, 2013, p. 45).

Людмила Митрофановна (Мила, Милочка) родилась в 1912 году в Новой Александрии небольшом гарнизонном городке, который сейчас находится на территории Польши, а тогда располагался в западной части Российской империи [Lyudmila (Mila, Milochka) Mitrofanovna was born in 1912 in Novaya Aleksandria, a small garrison town which is situated on the territory of Poland now, but then was located in the western part of the Russian Empire] (Lewycka, 2006, p. 62).

The absence of explanation of the historical Ukrainian phenomenon alien to the English culture, misleads presumably the target reader. Nevertheless, as the term is not in use now, Ukrainian and Russian translators substituted it by a contemporary variant.

The third subtechnique is based on the transliteration of Ukrainian words in the character's speech, combined with a calque translation in the author's words:

"Holubchik!" Little pigeon. My father glows (Lewycka, 2017, p. 82).

The lexeme holubchik is italicized, which shows its foreign character. The Ukrainian lexeme голубчик is defined in the dictionary of Ukrainian as colloquial ласкаве звертання до кого-небудь [affectionate address to someone] (Bilodid, 1971, р. 119), usually used in the vocative case голубчику (Bilodid, 1971, p. 119). The Ukrainian translation, nevertheless, presents the calque in the Nominative case голубчик instead of the vocative one, which might point to the level of the character's education:

- Голубчик!

Батько палає ['Holubchyk!' My father glows] (Lewycka, 2013, p. 70).

The Russian variant does not add any explanation either:

-Голубчик! Отеи покраснел ['Golubchik!’ My father blushes] (Lewycka, 2006, p. 96).

The given word is often used in the Russian language with the same meaning.

Lewycka also introduces an English calque expression my little pigeon which follows the transliteration holubchyk into the direct speech itself:

"Ah holubchik. My little pigeon." She beams, and gives him another peck on the cheek (Lewycka, 2017, p. 131). 
However, the English calque is rendered neither in Ukrainian nor in Russian translations:

- Ах, голубчик. - Вона сяє і ще раз цмокає його у щоку ['Ah holubchyk'. She shines, and gives him another kiss on the cheek] (Lewycka, 2013, p. 123)

- Мой ты голубчик... - Она ласково улыбнулась и еще раз чмокнула его в щеку ['Yои аre my golubchik'... She smiles kindly and gives him another kiss on the cheek] (Lewycka, 2006).

The calque my little pigeon is used by the author in the source text in order to make the Ukrainian lexeme understandable, but the Ukrainian and Russian translations are void of it as it is excessive in both target texts.

Table 3 Representation of lacunae within the strategy of foreignization

\begin{tabular}{|c|c|c|c|c|c|}
\hline \multicolumn{2}{|c|}{ English source text } & \multicolumn{2}{|c|}{ Ukrainian translation } & \multicolumn{2}{|c|}{ Russian translation } \\
\hline lacuna & technique & lacuna & technique & lacuna & technique \\
\hline intelligentsia & borrowing & інтелігенція & equivalent & интеллигенция & equivalent \\
\hline Mitrofanova & transliteration & Митрофанівна & $\begin{array}{l}\text { contemporary form } \\
\text { of the patronymic }\end{array}$ & Митрофановна & $\begin{array}{l}\text { contemporary } \\
\text { form of the } \\
\text { patronymic }\end{array}$ \\
\hline $\begin{array}{l}\text { Holubchik, } \\
\text { my little } \\
\text { pigeon }\end{array}$ & $\begin{array}{c}\text { transliteration, } \\
\text { calque } \\
\text { translation }\end{array}$ & голубчик & equivalent & голубчик & equivalent \\
\hline
\end{tabular}

\section{Conclusion}

Representation of Ukrainian culture-specific information regarding Ukrainian historical and contemporary lacunae which reflect phenomena connected with political life, society, administrative division, everyday life, and etiquette in the English source text and its rendering in Ukrainian and Russian target texts have been highlighted. When describing the Ukrainian lifestyle, the author of the English source text employs two major translation strategies: that of domestication, which makes the phenomena introduced by the author clear to the English-language reader and that of foreignization, which allows the writer to preserve a flavour of Ukrainian culture in the source text. The strategy of domestication is implemented through equivalent or near equivalent translations, whereas the strategy of foreignization is revealed through a Russian borrowing defining a typically Eastern Slavic phenomenon, transliteration, a combination of transliteration, and calque translations. However, in trying to find a balance between these two strategies, the author combines them, employs transliteration as a means of foreignization supplemented with a near equivalent, descriptive translation within the strategy of domestication, and uses calque translation within the framework of foreignization together with descriptive translation as a means of domestication. This enables the writer to preserve the unique character of the Ukrainian culture and make the lacuna comprehensible for the English-language reader. In the Russian translation, a borrowing from German, combined with the explanation of the phenomenon, is used to render the name of a typically Ukrainian dish. Moreover, the Russian translation shows similarity with the English source text regarding the usage of inverted commas and italics when lacunae are presented.

\section{References}

1 Akbari, A., \& Darani, P. A. (2017). The status of intercultural mediation in translation: Is it an absolute licence? Topics in Linguistics, 18(1), 59-70. https:/ /doi.org/10.1515/ topling-2017-0005

2 Chen, L. (2017). Cultures, communication, and contexts of intercultural communication. In Chen, L. (Ed.), Intercultural Communication (pp. 1-16). Boston/Berlin: Walter de Gruyter. https://doi.org/10.1515/9781501500060-001

3 Dun, N. L. (2007). Intralingvalnye lakuny v leksicheskoy sisteme russkogo yazyka [Intralingual Lacunae in the Lexical System of the Russian Language]. Visnyk Sumskoho derzhavnoho universytetu. Seria Filologia 1, 135-141. (In Russian). 
4 Eco, U. (2001). Experiences in Translation. (A. McEwan, Trans.). Buffalo, Toronto, London: University of Toronto Press.

5 Kalb, M. (2018). Enemy of the People: Trump's War on the Press, the New McCarthyism, and the Threat to American Democracy. Washington: Brookings Institution Press.

6 Kazazi, L. (2014). The lacuna as a cultural phenomenon: analyzing Martin Camaj's "Circles". Journal of Educational and Social Research, 4(4), 353-356. https://doi. org/10.5901/jesr.2014.v4n4p353

7 Lyubymova, S., Tomasevich, N., \& Mardarenko, O. (2018). On lacunarity in translation of culture specific concepts: Transletters. International Journal of Translation and Interpreting, 1, 65-78.

8 Markovina, I. Yu. (2004). Metod ustanovleniya lakun $v$ issledovanii etnopsikholingvisticheskoy spetsyfiki kultur [Method of Establishing Lacunae in Researching Ethno-Psycho-Linguistic Specificity of Cultures]. Voprosy psikholingvistiki, (2), 58-64. (In Russian).

9 Newmark, P. (1988). A Textbook of Translation. New York: Prentice Hall International.

10 Nida, E. A. (2003). Fascinated by Languages. Amsterdam: John Benjamins.https://doi. org/10.1075/z.119

11 Nida, E. A. (1964). Toward a Science of Translating. Leiden: E. J.Brill.

12 Nida, E. A. \& Taber, C. (1969). The Theory and Practice of Translation. Leiden: E. J. Brill. https://doi.org/10.2307/411434

Dictionaries and Sources
1 Bilodid, I. K. (Ed.). (1971). Slovnyk ukrainskoi movy [Dictionary of the Ukrainian Language] (Vol. 2). Kyiv: Naukova dumka. (In Ukrainian).

2 Bilodid, I. K. (Ed.). (1973). Slovnyk ukrainskoi movy [Dictionary of the Ukrainian Language] (Vol. 4). Kyiv: Naukova dumka. (In Ukrainian).

3 Bilodid, I. K. (Ed.). (1980). Slovnyk ukrainskoi movy [Dictionary of the Ukrainian Language] (Vol. 11). Kyiv: Naukova dumka. (In Ukrainian).

4 Busel, V. T. (Ed.). (2005). Velykyi tlumachnyi slovnyk suchasnoi ukrainskoi movy [Great Explanatory Dictionary of Modern Ukrainian]. Kyiv-Irpin: VTF «Perun». (In Ukrainian).

5 Chernyavskaya, T. N., Miloslavskaya, K. S., Rostova, Y. G., Frolova, O. Y., Borisenko, V. I., Vyunov, Y. A. \& Chudnov, V. P. (2007). Rossia. Bolshol Linvostranovedcheskiy Slovar [Rus-
13 Piller, I. (2007). Linguistics and intercultural communication. Linguistics and Language Compass, 1(3), 208-226. https:/ /doi. org/10.1111/j.1749-818X.2007.00012.x

14 Ramiere, N. (2006). Reaching a foreign audience: Cultural transfers in audiovisual translation. The Journal of Specialized Translation, 6, 152-166.

15 Slavova, L., \& Borysenko, N. (2018). Rendering cultural information in translation: English - Ukrainian direction. Odessa Linguistic Journal, 11, 167-173. https:/ /doi. org/10.32837/2312-3192-2018-11-167-173

16 Shveytser, A. D. (1988). Teoriya perevoda. Status, problemy, aspekty [Theory of Translation. Status, Problems, Aspects]. Moskva: Nauka. (In Russian).

17 Vlakhov, S., \& Florin, S. (1980). Neperevodimoye $v$ perevode [Untranslated in Translation]. Moscow: Mezhdunarodnye otnosheniya. (In Russian).

18 Yemelyanova, Y. B. (2010). Lingvostranovedcheskaya kompetentsiya perevodchika: teoriya i praktika: monografiya [Linguistic Country Study Competence of the Translator: Theory and Practice: Monograph]. Nizhniy Novgorod: OOO “Stimul-ST”. (In Russian).

19 Zorivchak, R. P. (1989). Realiya i pereklad (na materiali anglomovnykh perekladiv ukrainskoi prozy) [Realia and Translation (a Case Study of the English-Language Translations of Ukrainian Prose)]. Lviv: Vydavnytstvo Lvivskoho universytetu. (In Ukrainian).

sia. Great Linguistic Country Study Dictionary]. Moscow: State Institute of the Russian Language named after A. S. Pushkin. ASTPress. [viewed June 2020] Retrieved from https://lingvostranovedcheskiy.academic. ru/105/ВРАГ_НАРОДА

6 Collins Free Online Dictionary. Retrieved May 2020, from https://www.collinsdictionary.com

7 Dictionary by Merriam-Webster. Retrieved May 2020, from https://www.merriam-webster.com

8 Encyclopaedia Britannica. Retrieved May 2020, from https://www.britannica.com

9 Lewycka, M. (2013). Korotka Istoriia Traktoriv Po-Ukrainsky [A Short History of Tractors in Ukrainian]. (O. Negrebetskyi, Trans.). Kyiv: Tempora. (In Ukrainian).

10 Lewycka, M. (2006). Kratkaya Istoriya Trak- 
torov Po-Ukrainski [A Short History of Tractors in Ukrainian]. (V. Nugatov, Trans.). Moscow: Eksmo. (In Russian).

11 Lewycka, M. (2017). A Short History of Tractors in Ukrainian. London: Penguin Books.

12 Melnychuk, O. S., Bilodid, I. K., Kolomiiets, V. T., \& Tkachenko, O. B. et al. (Eds.). (1985). Etymolohichnyi slovnyk ukrainskoi movy [Etymological Dictionary of the Ukrainian Language], (Vol. 2 D-Koptsi). Kyiv: Publishing House Naukova Dumka. (In Ukrainian).

13 Ozhegov, S. I., \& Shvedova, N. Y. (1995). Tolkovyy Slovar Russkogo Jazyka: 80000 slov i frazeologicheskikh vyrazheniy [Explanatory Dictionary of the Russian Language: 80000 words and idioms] (2nd ed.). Moscow: "AZ". (In Russian).

14 Shynkaruk, V. I., Bystrytskyi, Y. K., \& Bulatov, M. O. (2002). Filosofskyi Entsyklopedychnyi
Slovnyk [Philosophical Encyclopedic Dictionary]. Kyiv: Abrys. (In Ukrainian).

15 Ushakov, D. N. (Ed.), (1935). Tolkovyy Slovar Russkogo Yazyka [Explanatory Dictionary of the Russian Language], (Vol. 1: A - Kyuriny). Moscow: State Inst. "Sov. Entsikl", OGIZ. (In Russian). Retrieved May 2020, from https:// ushakovdictionary.ru

16 Yefremova, T. F. (2000). Novyy Slovar Russkogo Yazyka. Tolkovo-slovoobrazovatelnyy [New Dictionary of the Russian Language. Explanatory-Derivational]. Moscow: Russkiy Jazyk. (In Russian). Retrieved May 2020, from https://www.efremova.info

17 Yevgenyev, A. P. (Ed.), (1999). Malyy Akademicheskiy Slovar [Concise Academic Dictionary] (Vol. 2, K-O). (4th ed.). Moscow: "Russkii Yasyk" Poligrafresursy. (In Russian). Retrieved May 2020, from http://feb-web.ru/ feb/mas/mas-abc/default.asp

\section{Santrauka}

Liudmyla Slavova, Natalia Borysenko. Specifinès leksinių atitikmenų neturinčios kultūrinès informacijos perteikimo strategijos

Straipsnyje nagrinejamas specifinè ukrainiečių kultūrinè informacija Marinos Lewyckos romane A Short History of Tractors in Ukrainian. Ši informacija užkoduota beekvivalentejje leksikoje (lakūnose), o autoriaus ir vertèjo užduotis šią informaciją iššifruoti pasitelkiant atitinkamas vertimo strategijas. Išskirtos šios strategijos: 1) savinimo (ang. domestication) strategija (kai vertime naudojamas tikslus arba apytikslis atitikmuo); 2) savinimo ir svetinimo (ang. foreignisation) strategijų derinys (transliteracija kartu su apytiksliu atitikmeniu ir aprašomuoju vertimu ar vertinys (kalkè) kartu su aprašomuoju vertimu); 3) svetinimo strategija (skolinys ir transliteracija atskirai arba kartu su vertiniu). Kaip pagalbinès taip pat naudojamos grafinès priemonès (kabutès ir kursyvas). Romano vertimai i ukrainiečių ir rusų kalbas rodo, kad atitikmenų neturinti leksika daugiausia keičiama atitinkamomis ukrainiečių ir rusų leksemomis. Nustatyta, kad archajiškos formos kartais keičiamos šiuolaikinèmis, taip pat naudojami savi (autentiški) elementai ir skoliniai. Straipsnyje taip pat aptariama, kad ịvairiomis priemonėmis perteikiant specifinę kultūrinę ukrainietišką informaciją šaltinio tekste anglų kalba bei vertimuose i ukrainiečių ir rusų kalbas siekiama rasti pusiausvyrą tarp savinimo ir svetinimo strategijų.

About the Authors

\section{LIUDMYLA SLAVOVA}

Doctor of Sc. in Philology,

Professor at Taras Shevchenko National

University of Kyiv, Ukraine

Research interests

Contrastive linguistics, contrastive semantics, cognitive linguistics, linguistic personality, discourse analysis.

Address vul. Volodymyrska, 60, Kyiv, Ukraine

E-mail slavovall16@gmail.com

\section{NATALIA BORYSENKO}

Candidate of Sc. in Philology, Associate Professor at Zhytomyr Ivan Franko State University, Ukraine

Research interests

Discourse analysis, translation studies, contrastive semantics, pragmatics.

\section{Address}

vul. Velyka Berdychivska, 40, Zhytomyr 10008, Ukraine

E-mail

nat.dbor@gmail.com 